\title{
MUSLIM MINORITY IN MYANMAR: A CASE STUDY OF MYANMAR GOVERNMENT AND ROHINGYA MUSLIMS
}

\author{
ISMAIL SUARDI WEKKE ${ }^{1}, \mathrm{HASBI}^{2}, \mathrm{M}^{\mathrm{MAWARDIN}}{ }^{3}$, \\ SUYATNO LADIQI ${ }^{4}, \mathrm{MOHD}^{2}$ AFANDI SALLEH ${ }^{4}$ \\ 1,2 Sekolah Tinggi Agama Islam Negeri Sorong \\ ${ }^{3}$ Universitas Hasanuddin \\ ${ }^{4}$ Universiti Sultan Zainal Abidin, Terengganu, Malaysia
}

\begin{abstract}
The discrimination suffered by Rohingya Muslims is increasingly blewed up in media in last decade. The peak of the discriminatory treatment against Rohingya Muslim by Myanmar government is the unavailability of shelter from Myanmar government. In the perspective of international law, Myanmar government's actions constitute a serious violence, because it ignores the rights of its citizens. Even a series of massacres and inhumane treatment became a major offense committed by Myanmar government in terms of humanity. This attracted international attention in solving the problem. This article illustrated the fate of Rohingyas who are not given citizenship rights by Myanmar government. It also revealed the irony of Muslims of Rohingya life who are discriminated by the government of Myanmar, both in the practical as well as in the political context.
\end{abstract}

Diskriminasi yang diderita oleh Muslim Rohingya semakin mengemuka di media dalam dekade terakhir. Puncak perlakuan diskriminatif terhadap Muslim Robingya adalah tidak tersedianya tempat tinggal dari pemerintah Myanmar. Dalam perspektif hukum internasional, tindakan pemerintah Myanmar ini merupakan

Corresponding author; email: ${ }^{1}$ iswekke@gmail.com, ${ }^{2}$ hhasbi@gmail.com, ${ }^{3}$ mmawardin@gmail.com, ${ }^{4}$ suyatno.ladiqi@gmail.com, ${ }^{5}$ afandisalleh@gmail.com

ISSN 0852-7172 (p) 2461-064X (e)

(C) 2017 Walisongo: Jurnal Penelitian Sosial Keagamaan

http://journal.walisongo.ac.id/index.php/walisongo 
bentuk kekerasan yang serius, karena mengabaikan hak warganya. Selain itu serangkaian pembantaian dan perlakuan tidak manusiawi menjadi pelanggaran besar yang dilakukan oleh pemerintah Myanmar dalam hal kemanusiaan. Hal ini menarik perhatian dunia internasional dalam upaya memberikan solusi atas permasalahan-permasalahan tersebut. Artikel ini selain menggambarkan nasib warga Rohingya yang tidak diberikan hak kewarganegaraan oleh pemerintah Myanmar, juga mengungkap ironi Muslim dari kehidupan Rohingya yang didiskriminasi oleh pemerintah Myanmar, baik dalam praktik maupun dalam konteks politik.

Keywords: discrimination; Muslim; Myanmar government; Rohingya.

\section{Introduction}

Myanmar, also known as Burma, gained its independence from Britain in 1948 and was ruled by the military junta from 1962 until it was dissolved after the election in 2010. A new political atmosphere has marked the transition from military rule to civilian government in 2011, on the hands of President Thein Sein. Unexpected changes have occurred after the release of NLD leader, Aung San Suu Kyi, and the start of a new dialogue between the newly elected President and the opposition leader (Gaetanol 2013).

Broadly speaking, Rohingya is an ethnic-patterned Muslim group that originated from northern Rakhine, the western part of Myanmar that was once called Arakan. The arrival of Muslim traders from the Arabs in the place became a marker of the history of Rohingya in the early seventh century. Therefore, Rohingyas can be recognized in terms of physical, language and also the culture which are almost the same as the Asian people, namely the Bengali people. But ironically Rohingyas rarely get the attention of the local government. The researchers were still 
lacking the attention to elaborate Rohingya as Muslim minority in Myanmar which became refugees in the south and parts of southeast Asia.

In the context of Rohingya problem, there are three major (distinctive) issues relating to the law. In addition, there are different facts that require a special review involving (1) citizenship and discrimination, which exclusively focus on Myanmar; (2) citizenship and transfer, which also involve neighboring Myanmar; and (3) the doctrine of Responsibility for Protecting, which refers to the role of the international community ( $\mathrm{Za}$ wacki 2013). Referring to the context, factually the problem is not only Rohingya community problem, but also the Myanmar government, the countries surrounding Myanmar, and the international community.

According to the Amnesty International (AI) report, since 1978 Rohingya have suffered from human rights violations committed by the military junta in Myanmar, and many have fled to neighboring countries such as Bangladesh. Their citizenship is rejected by Myanmar government and their human rights seem to be ignored by the local government. More than 200,000 Rohingyas had fled to Bangladesh in 1978, and based on new information, it was reported that more than 250,000 Rohingyas fled. An estimated 20,000 Rohingya refugees are living in the United Nations High Commissioner (UNCHR) for border areas camping at Cox's Bazaar in Bangladesh. Human rights activists said that Rohingya's human rights had been abused and exploited, forcing many to flee to Bangladesh (Amnesty International 2004). Thousands of Rohingyas left Myanmar on boats and many of them went to Bangladesh and Thailand by sea and then by land to Malaysia (Zarni and Cowley 2014).

After the denial of citizenship followed by the military junta in 1962, Rohingya is subjected to continuous torture. As a result, 
they flee and travel everywhere. For decades they are desperate to seek refuge for a better life (Ragland 1994). But they are very excluded because they have no legitimate citizenship or nationality. Ironically, the majority of them is told to move or is forced to move to Bangladesh, Thailand, India, Pakitan, Saudi Arabia, and Malaysia. Even if they can move away from other places they like, the suffering does not end because they have limitations with their status. They experience discrimination, trafficking, poverty, arrest, extortion, and deportation (Lewa 2009).

The Rakhine State, historically known as Arakan State, positions in the west of Myanmar. Its capital Sittwe, located in the Bay of Bengal in the west, and areas affected by inter-group violence with Bangladesh to the northwest. The Rakhine region shares the borders with Chin State in the north and east with Magway and Bago Territories. West Myanmar is populated by Rakhine Buddhists and Rohingya Muslims (Gaetanol 2013; Zarni and Cowley 2014).

The law that Myanmar has practiced since 1982 to date on the right of citizenship is a proof of human rights violations that struck Rohingyas in Rakhine (Arakan). Imtiaz (2010) mentioned that there are two we should know about the discriminatory treatment affecting Rohingya Muslims in Arakan. The first, in 1982 Rohingyas citizenship rights were rejected by Myanmar government in the military junta. Second, the military junta strongly suspected these people (Rohingyas) as new people coming from Bangladesh. Meanwhile, other tribes in Myanmar such as Karen, Shan, Dagu, Kachin, and Mon, were given excellent treatment, even their needs were all well-organized (Ahmed 2010). This indicates that the government of Myanmar has not paid much attention to Rohingya Muslims, because their tribe is still confusing, rather than other tribes that have been organized by the government of Myanmar. From the contrasting point 
of views, they hold that Rohingyas are unorganized or seldom touched by outsiders, so Rohingyas are often forgotten and neglected by outsiders.

Myanmar is a country rich in ethnic and religious diversity. Myanmar has 135 ethnicities. The most dominant ethnic groups in Myanmar are Bamar, Shan, Kayni, Rakhine, Chinese, Mon, and Kachin (Ardani, Wahyudi, and Susetianingsih 2015). The tragic story of Rohingyas invites our attention. This violation adds a dark record of the human rights violations that occurred in the world. Minorities are not always treated well in the occupied territory. Human rights violations are often experienced by minorities. This violates the UN Law of Article 7 which says that all are equal within the law and are entitled without discrimination under equal protection of the law. All are entitled to equal protection against any discrimination in violation of this Declaration and against incitement to such discrimination. With the development of events that occur, one in Myanmar, Rohingya conflict is a conflict based on discrimination due to ethnic and religious differences (Karim et al. 2016).

Myanmar government's legal and political policy towards Rohingya ethnic minority becomes a relevant international legal issue. First, Rohingya Muslim minority that has lived for centuries in Myanmar is a historical fact. The treatment of governments that do not recognize them as citizens has raised the question of law and human rights because discriminatory political policies between one tribe and another are contrary to the Convention against Anti-Discrimination as well as the Civic Convention.

This paper was based on normative and theoretical legal research using comprehensive literature with normative or legal doctrine approach supported by a review of normative legal concepts and rules. In addition to primary legal materials, 
secondary materials consisting of articles, journals, and magazines, as well as other relevant media were also used as an effort to strengthen the argument over the problem. Given Rohingya Muslim minority are immigrants, the historical and legal approach to international importance becomes very important. Based on the above argument, this article will discuss the fate of Rohingya Muslim minority in Myanmar and Myanmar's legal and political policies against Rohingya ethnic minority in the perspective of international law.

\section{Rohingya Muslim Minority}

According to some historians, Rohingya does not belong to Myanmar. Meanwhile, others believe Rohingya has lived there for hundreds of years. The polemics surrounding Rohingya's origins are the result of a political struggle, a misguided notion of national identity, intolerance, and discrimination. The truth is that in general, Rohingya Muslims have lived in western Myanmar before the British occupation of the province (Gaetanol 2013). Rohingya Muslim minority in Myanmar has been an isolated society in the place of its birthplace. Some of the factors that are historical, legal, and socioeconomic can explain why Rohingya Muslim minority has no citizenship status and become a victim of the malignancy of some of the Burmese authorities.

Firstly, Rohingyas are originally immigrants who came to Burma a few centuries ago. Some argue that Rohingyas originated in Arabic rahama (affectionate) and originated from the sultanate in Bengal. From posture and language, they tend to have a common physical and linguistic look with the Bangladesh people. Their language use is related to the Chitagonian language used by most people in the southern border region of Bangladesh. Geographically, the Arakan region (Rakhine) most of them live in the borders between Bangladesh and Arakan of 
West Burma (Myanmar).

In the 1945s, under Japanese rule, the establishment of the Burmese state began to occur through a process of social and political integration. More than 130 tribes negotiated and signed the declaration in a document on Myanmar's independence. Not so much information is obtained why Rohingyas were not involved in the initial Myanmar State establishment process. This political document became the first fact of the emergence of the exclusion policy in Myanmar against Rohingya Muslim minority.

Burmese historians recognize that the term Rohingya has not been known for certain since before the 1950s. The existence of Bengali and Bangladeshi descent which migrated to Arakan is much closer to the truth. The development of Islamic teachings has certainly come long before the presence of Rohingya. The Islamic sultanate in Bengal, which was very influential in 1824, can be a historical evidence of the origins of Rohingya Muslims in Myanmar (Fasya 2012).

Generally, they come to Indonesia to seek political asylum because of expulsion and massacre. Around 1988, Rohingyas were oppressed when the military came to power in Myanmar. In 1990 Rohingyas were allowed to vote in elections. About $80 \%$ of Rohingyas voted for the Democratic League Party, led by Aung San Suu Kyi, who was an opponent and a military enemy. However, the political contribution of Rohingya Muslim minority was also not recognized by Aung San Suu Kyi, who was known as an important political figure as well as a human rights activist in Myanmar. Suu Kyi argued that the "Rohingyas are illegal immigrants".

Furthermore, secondly, Rohingya Muslim minority became citizens without citizenship status as a result of legal and political policies. Since the enactment of the Immigration Act, in 
1974, the Government of Myanmar has provided the identity cards for the population. Except for Rohingyas, all Indian, Chinese, Bangladeshi and Burmese tribes such as Chin and Karen (indigenous people) obtained identity cards as citizens. Rohingya only obtained Foreign Registration Cards. The situation was becoming increasingly difficult for Rohingya Muslim minority because the Burmese Government passed the 1982 Citizenship Act which divided citizenships into three groups: full citizenship, associated citizens, and naturalized citizens. Rohingya does not get citizenship because it only has status as a foreigner.

In addition, there was a political reason, that Rohingya tribe who lived in Arakan once demanded political autonomy by fighting against the Government of the military junta in 1948. This claim made the indigenous Burmese tribes did not like Rohingyas (Siddiqui 2005). Rohingyas' image was deteriorated when some of them allegedly engaged in Al-Qaeda's network as a terrorist movement. This is the antagonistic attitude that drove horizontal conflict and violence.

Thirdly, the consequences of such discriminatory laws and political policies created the socio-economic conditions of Rohingyas worsened. They can not live worthy of decent work, educational, and health services. Their lives were not prosperous. Even since 1994, forced labor policies for both children and parents have been imposed. The act of confiscation of their properties by unlawful means by a group of people continued to make them powerless (Saragih 2017; Arfiani 2018). Initially, the military junta's government, President Thien Sien had no concern for the expulsion of society. So that, not surprised that they generally became poor people. Villages and border areas were particularly vulnerable to various security threats of crime. The military power of junta allowed the expulsion and destruction of properties and the deprivation of their properties. Many Ro- 
hingyas became civil servants, then dismissed for no apparent reason.

\section{Discrimination Against Rohingyas in Myanmar}

The pressure from the Burmese Government and the Rakhine indigenous people towards Rohingya was increasing. Horizontal conflicts between Rohingyas and the original Rakhine tribe were never resolved comprehensively. Tens of thousands of Rohingyas left the place to become refugees then went to more decent and safer countries. For example, in May 2012, a conflict broke out between ethnic Rohingya and ethnic Rakhine. The conflict began when a forensic photo was circulated about the murder of a woman of Rakhine named Ma Thaida Htwe that occurred on May 28, 2012, by three Rohingya youths (Thontowi 2013; Mitzy 2017; Mali 2017). Monks and Rakhine people demonstrated "No Rohingyas", killed Rohingyas, damaged buildings of worship, and damaged shelters. The conflict resulted in more than 70 people dying, more than 3,000 damaged buildings, and nearly 60,000 people homeless and forced to flee to Malaysia, Thailand and Indonesia (Yulia Hartati 2013; Sawal 2017; Rosyid 2012).

Bangladesh as one of the closest countries to Myanmar firmly rejected the presence of Rohingya refugees due to overpopulation reason. The attitude was also seen when the Government of Bangladesh refused foreign aid to set up refugee camps in the border region. Since 1978, about 200,000 people have fled to Bangladesh; from 1991 to 1992 about 10,000 people fled to Bangladesh in 1992, some 270,000 to Bangladesh (Parnini, Othman, and Ghazali 2013; Parnini 2013; Lall 2006; Cheung 2012). Such violent acts became a valid reason for them to be refugees. 
The threat of humanitarian catastrophe was very threatening to their lives. Myanmar government insisted that Rohingyas were classified as a non-citizen occupation "Rohingya minority group, classified as stateless Bengali Muslims from Bangladesh since 1982" (Bhuiyan 1982; Glass et al. 1982; Hashmi 2000). The state policy that made Rohingya stateless is a violation of the Citizenship Convention, including violation of the Civil Rights Convention to occupy or leave a state (ICCSR 1960), particularly related to Article 33 Paragraph (1) concerning the expulsion or refoulment (Paul and Hall 1999).

The government policy of Myanmar that was discriminative led to the humanitarian tragedy against Rohingya Muslim minority. Firstly, the Burmese Government committed murder, or cleansing, expulsion, and seizure of Rohingya minority properties. On March 28, 1945, there had been what they called Rohingya's Massacre since the incident killed nearly 100,000 people in Arakan. Next, Kalagong Massacre, July 1945, about 600 people were killed. The policy of expulsion or destruction of Rohingyas, according to Habib Siddiqi, was the removal of the history and culture of their ancestors from the family land (the history and culture to their ancestral land were conveniently ignored). This was a proof of the existence of King Dragon operation controlled by the Burmese Government.

King Dragon Operation, a major and structured national operation with the focused program to register citizens in the country of Myanmar and screen out foreigners prior to national census in 1977 (Cheung 2012). In this operation, it was noted that so many numbers of in which men, women, young and old were tortured, raped, and killed in Ahyab Village, north of Arakan (Siddiqui 2005). The fact showed at that operation, the Buddhist military regime has become a brutal, savage, and tyrannical ruler. The Buddhist leaders who were usually as the savior of 
the community, even provoked their people to drive Rohingyas away from the Rakhine region instead. The consequence is the increasing numbers of Rohingya become refugees, going out of Myanmar (Cheung 2012).

On May 30, 2003, there was a violence in an area of Myanmar, which killed more than 70 people. While the latest data, related to the bloody tragedy of June 28, 2012, 650 Rohingya were killed and 1,200 were lost. No less than 80,000 people lost their homes. These data are different from those reported by the Burmese Government that the conflict between Rakhine Buddhism and Rohingya Muslim minority has left about 78 dead, 87 injured and hundreds of homes destroyed. Although the alleged crimes of genocide or massacre are still being debated, the bloody tragedy of Rohingya minority has been classified as the most serious crime of humanity. The UN Human Rights Council reported that Rohingya minority was considered as a society that is suffering and forgotten by the world community.

Myanmar is one of the countries in Southeast Asia and also a member of the United Nations since April 4, 1948. As part of the members of the United Nations, Myanmar is obliged to respect the provisions contained in the Universal Declaration of Human Rights (UDHR) or the Universal Declaration on Human Rights and the UN Charter. However, the role of UNHCR (UN High Commission for Human Rights) only as a helper and temporary as they can not penetrate the policies adopted by the government of Myanmar so that the efforts of the United Nations cannot prevent discrimination by the government of Myanmar. This is evidenced by Rohingya problem to date consistent with the continued assistance of UNHCR (Myanmar High Commissioner of Refugees) in Myanmar (Karim et al. 2016).

Many of the UDHR provisions have been violated by the government of Myanmar, among others, the right to life (Article 
3) to not be tortured (Article 5), on the right to have citizenship (Article 15), and the right to have something (Article 17). In addition to violations of the UDHR provisions, Myanmar parliamentarians have an obligation to maintain world peace and security as defined in the Charter of the United Nations. Based on the above description, it is clear that human rights violations in Myanmar are very scary and can be categorized as serious types of human rights violations. The United Nations as a body that has the function to uphold human rights and peace in the world naturally plays a role in restoring the situation in Myanmar. The United Nations Security Council, which is the main organ of the United Nations assigned to safeguard international peace and security, must issue a decision to create a democratic and secure state of Myanmar (Karim et al. 2016).

Among the strategies and activities of UNHCR in Myanmar in 2013, to advocate for the Government to grant citizenship to Rohingyas was the application of limiting legal practice and helping the Government to realize its responsibilities to people affected by displacement, both Rohingya and Rakhine Buddhists. UNHCR would also strengthen partnerships with civil society, academic institutions, and NGOs while enhancing dialogue with new Civil Government. It would collaborate with all the stakeholders involved to improve Rohingya's condition without citizenship status (Gaetanol 2013; Lewa 2009).

Violations committed by the Government of Myanmar against international law are as follows. First, the Government of Myanmar is seen as violating the Convention on Citizenship. Each State has an obligation to provide citizenship security so that there is no stateless citizen (Vienna Convention on Consular Relations and Optional Protocol to The Vienna Convention on Consular Relation Concerning Acquisition of Nationality 1963).

The Government of Myanmar that has allowed Rohingyas 
to have no stateless entities, is clearly a violation because they have been living for centuries in Myanmar. The 1974 Immigration Act and the 1982 Citizenship Act are clearly inconsistent with the Convention on the Elimination of All Forms of Racial Discrimination/CERD 1965. Violations of Human Rights and the Citizenship Convention are very clear because the Government of Myanmar has isolated Rohingyas and let them have no citizenship.

The Burmese government leaves conflict and violence between the Rakhine tribe and Rohingyas continuous and systematic. Teuku Kemal Fasya (2012) asserted that the government's attitude is to allow unequal ethnic conflict to even ally with the dominant Rakhine ethnic Buddhist religion in Arakan. UN Charter Article 2 Paragraph (3): All members shall settle their international disputes by peaceful means that the international peace and security, and justice, are not endangered. The facts show that the deaths, disappearances, and expulsions are seen to be in violation because the government is seen as not performing the international obligation of preventing violence that threatens world peace.

Some state tools, police, and soldiers that were involved in Rohingya tribal massacre is also a form of violation of the state's obligation not to allow the use of force (Declaration of State Accountability). The International Human Rights Watch report confirmed that Myanmar's army that was supposed to protect and safeguard sectarian conflict, actually shooted Rohingya's ethnic Muslim, while army personnel raped citizens (Pos 2012).

Rohingya is the name of an ethnic group inhabiting the Arakan region, western Myanmar, and directly bordering on Bangladesh. Rohingya is one of 135 ethnic groups in Myanmar. Rohingya Muslims are the people who actually grew up and lived since the 7 th century AD. Rohingya ethnicity for decades 
has been discriminated, even now without citizenship. Rohingya has not been recognized by the Government of Myanmar and is not granted citizenship. This is evidenced by the issuance of Burma Susanti Myanmar Citizenship Rule in the Citizenship Act of 1982 (2014) when Myanmar removed Rohingya from the list of eight major Burman ethnic, Kachin, Karen, Karenni, Chin, Mon, Arakan, Shan, and 135 more small. They are considered not citizens, no documents about them. If there is no document and place for them, they are not allowed to go from one place to another, there are laws that protect the association, even isolate love, eventually, they find their way (Karim et al. 2016).

Under International Law, human rights must be guaranteed for citizens with non-citizen status. The principle of equality and non-discrimination prohibits discrimination on the basis of citizenship. Therefore, the legal status of stateless persons under national law should reflect the applicable provisions of international law on human rights. The 1954 Convention is supported by international human rights law, but some international provisions are, based on higher standards of rights, not found in the Convention at all. At the same time, the 1954 Convention remains significant because it deals with issues specific to statelessness, such as the provision of identity documents and travel documents that are not handled elsewhere (Gaetanol 2013; Starke 1989).

\section{Discrimination to Rohingya Based on the Eye of International Law}

From the above study, the author holds that the fundamental thing we should question is about the status of Rohingya because, from various sources obtained by the researchers, the status of Rohingya is not so clear. Some mention that Rohingya comes from Bangladesh according to posture, face, and lan- 
guage. But in essence, Bangladesh does not recognize Rohingyas and even refuse to be called its citizens. Bangladesh still believes that Rohingyas are from Rakhine in northern Myanmar.

Similarly, Myanmar has claimed that Ethnic Rohingya is a foreign tribe who came from abroad, so Rohingyas are always suspected of being foreigners seeking asylum in Myanmar. The act of Myanmar government is a discriminatory act against Rohingyas, in which Myanmar does not consider them as citizens. In this case, the authors have another view, that when Myanmar does not recognize Rohingya as its citizen, because Rohingyas are indeed different from the other tribes. From the look on the face, the color, and the language, Rohingyas are indeed similar to the Bengalis, so Myanmar government believes that Rohingyas are from the Bengali tribe directly bordering on Bangladesh.

In this context, the big problem is that each of the two nations does not recognize Rohingyas as citizens, so Rohingyas up to now have no citizenship rights. But apart from that all, Rohingya tribe is very apprehensive because it cannot find worth living like other citizens who can freely find a job anywhere in the country. Actually, there is a good policy from Myanmar government for Rohingya tribe, because Rohingya tribe does not demand independence from Myanmar government, they just want to be recognized as citizens having their own rights. But it was not also met. Precisely the intimidation and suspicion of Myanmar government is very severe against Rohingyas.

In fact, there are so many minorities in different countries in the world who are discriminated against by their governments. Most minorities are subjected to torture for the limited access to the right to a decent life. In the case of Rohingya Muslim minority in Myanmar, they are tortured and forced to evacuate, while governmental and international authorities have not yet comprehensively addressed the issues they face. In fact, very 
clearly, this is a severe violation of human rights committed by the government of Myanmar, even classified as violating the principles of international law.

Protection for various ethnicities and measures to combat racial discrimination has been made by the United Nations by adopting a number of resolutions, conventions, and declarations. In the first world conference to eradicate racism and racial discrimination, states are urged to eliminate discrimination on the basis of ethnic or national background and to protect and promote the human rights of ethnic minorities and nationalities. The Conference recommends States to adopt special economic, social, educational, cultural, and civil rights and political measures to ensure that everyone enjoys legal equality, ensuring that discrimination between majority and minority has been eliminated (Tampubolon, Rahman, and Bariah 2013).

Some of the international instruments governing minority groups are: First, Convention on the Prevention and Punishment of the Crime of Genocide stipulated through UN General Assembly Resolution 260 A (III) on December 9, 1948. This Convention came into force on January 12, 1951. The Convention on the Prevention and Punishment of the Crime of Genocide is the first human rights treaty authorized by the UN General Assembly 25. The Convention focuses on the protection of national, racial, ethnic, and religious minorities from threats against their existence. The Convention on the Prevention and Punishment of the Crime of Genocide also includes the definitions of genocide and deeds classified as genocide. Article II of this Convention states:

"In the present Convention, genocide means any of the following acts committed with intent to destroy, in whole or in a part, a national, ethnical, racial or religious group, as such: (a) Killing members of the group; (b) Causing serious bodily or mental harm to members of the group; (c) Deliberately inflict- 
ing on the group conditions of life calculated to bring about its physical destruction in whole or in part; (d) Imposing measures intended to prevent births within the group; (e) Forcibly transferring children of the group to another group."

Second, International Convention on the Elimination of all Forms of Racial Discrimination stipulated through Resolution 2106 (XX) of General Assembly, December 21, 1965, and entered into force on 4 January 1969. Previously, on 20 November 1963, UN member states have made Declaration on the Elimination of All Forms of Racial Discrimination through Resolution 1904 (XVIII). The Declaration contains a rejection of racial discrimination by governments and some societies, cessation of racial propaganda, and measures to be taken by countries in the elimination of racial discrimination. To follow up the Declaration, the UN Human Rights Commission then adopted the International Convention on the Elimination of All Forms of Racial Discrimination. These International Instruments are complementary to the specificity of the protection for the rights set forth therein. Protected rights include protection from genocide, torture, and ill-treatment, protection for the promotion of identity, the right to education, and so on (Tampubolon, Rahman, and Bariah 2013).

In another international legal instrument, the International Covenant on Civil and Political Rights, adopted by General Assembly Resolution 2200 A (XXI) of 16 December 1966 and entered into force on 23 March 1976, Article 27 of the Covenant states that the protection for minority groups in a country not only aimed at the ethnic group which has been recognized and has obtained citizenship status but also applies to ethnic groups who do not have citizenship status, they are also entitled to enjoy the rights protected in that provision (Tampubolon, Rahman, and Bariah 2013). 
The legal instruments of international law above can be used as a juridical basis to overcome the problems faced by Rohingya. More than just a matter of the legality of citizenship, Rohingya is also associated with historical problems in the struggle of ethnicity in Myanmar's national realm. Myanmar government's discriminatory action made them into boatmen by fleeing to other countries for protection, assistance, and support. Due to their stateless status, they are also difficult to get their rights as citizens. Under the local Citizenship Act in Rakhine Province, Myanmar, Rohingya Muslim group is not given citizenship. So, Myanmar government is clearly violating human rights and violating international law. This requires the strategic role of international organizations to overcome the complexity of the existence and legality of Rohingya.

\section{Conclusion}

Based on the above description, it is clear that Myanmar government's legal and political policies towards Rohingya minority are lame since Rohingya has a historical connection with the growth of modern countries in the Asian sub-continents, like Pakistan, India, Bengal Bangladesh, and Burma. Historically, as well as linguistically, Rohingya minority is closer to the historical origins of kinship with the Bengali people of Bangladesh. The location of the Arakan (Rakhine) which lies on the border between Burma and Bangladesh reinforces the above assumption. So it is not too difficult to trace that Rohingya has a kinship with Bangladesh. The fate of the marginalized Rohingya minority is, in fact, a dynamic and conflict between indigenous peoples (Burmese) and immigrant tribes such as China and India.

In the domestic political context of Myanmar, Rohingya has contributed to it by participating into a political constituency supporting the National League for Democracy Party (NLD) led 
by Aung San Suu Kyipada in the 1992s. But they still did not get any benefit because the military junta of Myanmar is not willing to release the power to the civil society. Rakhine society's suspicion to Rohingya is about the issues of radicalism attached to them. In addition, there are also political factors that are of strategic importance of the UK. On the other hand, the demands of autonomy become a special issue that is complex. Rohingya's lack of participation in the signing of Myanmar's State establishment documents and being alleged to be involved with al-Qae$\mathrm{da}$ organizations are contributing factors to the discrimination against them.

\section{Bibliography}

Ahmed, Imtiaz. 2010. The Plight of the Stateless Rohingyas: Responses of the State, Society \& the International Community. Bangladesh: University Press Ltd.

Amnesty International. 2004. "Myanmar Rohingya Minority: Fundamental Rights Denied."

Ardani, Fatma Arya, Fendy Eko Wahyudi, and Hermini Susetianingsih. 2015. "Kebijakan Indonesia Dalam Membantu Penyelesaian Konflik Antara Etnis Rohingya Dan Etnis Rakhine Di Myanmar (Studi Karakter Kepribadian Susilo Bambang Yudhoyono)." Journal of International Relations 1 (2). Diponegoro University: 22-28.

Arfiani, Y. I. 2018. "Pengelolaan Dana Zakat Produktif Dalam Program Ternak Master Di Lazis Yayasan Badan Wakaf Universitas Islam Indonesia.” Universitas Islam Indonesia.

Bhuiyan, Md. Abdul Wadud. 1982. Emergence of Bangladesh and Role of Awami League. New Delhi: Vikas.

Cheung, Samuel. 2012. "Migration Control and the Solutions Impasse in South and Southeast Asia: Implications from the Rohingya Experience." Journal of Refugee Studies 
ISMAIL SUARDI WEKKE, ET AL.

25 (1). Oxford University Press: 50-70. doi:10.1093/jrs/ fer048.

Fasya, Teuku Kemal. 2012. "Dilema Rohingya Dan Demokrasi Myanmar.” Kompas.Com, August 3.

Gaetanol, Silvia di. 2013. "How to Protect the Rights of the Stateless Rohingya People in Myanmar?" The Asian Resource Foundation. Bangkok.

Glass, R I, S Becker, M I Huq, B J Stoll, M U Khan, M H Merson, J V Lee, and R E Black. 1982. "Endemic Cholera in Rural Bangladesh, 1966-1980." American Journal of Epidemiology 116 (6). Oxford University Press: 959-70.

Hashmi, Taj I. 2000. Women and Islam in Bangladesh: Beyond Subjection and Tyranny. London: Palgrave Macmillan UK. doi:10.1057/9780333993873.

Karim, Zamzami A., Ali Jeihan, Nurfajar Efendi, Nanda Rizky Hidayat, and Vira Adrini Zain. 2016. "UN Rolein The Fight Violation Human Rights: Case Study Regarding Rohingyain Myanmar." In The Challenges of Social Sciences in a Changing World, 853-60. Yogyakarta: Jusuf Kalla School Of Government (JKSG) Universitas Muhammadiyah Yogyakarta.

Lall, Marie. 2006. "Indo-Myanmar Relations in the Era of Pipeline Diplomacy." Contemporary Southeast Asia 28 (3). ISEAS Yusof Ishak Institute: 424-46. doi:10.2307/25798799.

Lewa, Chris. 2009. "North Arakan: An Open Prison for the Rohingya in Burma." Forced Migration Review, no. 32: 11-13.

Mali, Fransiskus X. Gian Tue. 2017. "Peluang Asean Community Menyelesaikan Masalah Rohingya.” Asia Pasific Studies 1 (1): 1-14.

Mitzy, Gulia Ichikaya. 2017. "Perlawanan Etnis Muslim Ro- 
hingya Terhadap Kebijakan Diskriminatif Pemerintah Burma-Myanmar." Global South Review 1 (2): 153-64.

Parnini, Syeda Naushin. 2013. "The Crisis of the Rohingya as a Muslim Minority in Myanmar and Bilateral Relations with Bangladesh.” Journal of Muslim Minority Affairs 33 (2). Routledge: 281-97. doi:10.1080/13602004.2013.826 453.

Parnini, Syeda Naushin, Mohammad Redzuan Othman, and Amer Saifude Ghazali. 2013. "The Rohingya Refugee Crisis and Bangladesh-Myanmar Relations." Asian and Pacific Migration Journal 22 (1): 133-46. doi:10.1177/011719681302200107.

Paul, T. V., and John A. Hall, eds. 1999. International Order and the Future of World Politics. Cambridge: Cambridge University Press.

Pos, Jawa. 2012. “Tentara Myanmar Tembaki Muslim Rohingya." Jawa Pos, August 2.

Ragland, Thomas K. 1994. "Burma's Rohingyas in Crisis: Protection of Humanitarian Refugees under International Law." Boston College Third World Law Journal 14 (2): 301-36.

Rosyid, Moh. 2012. “Menggugah Peran Hukum Humaniter Internasional Islam Dalam Mengurai Konflik Etnis Perspektif Sejarah." Ijtihad : Jurnal Wacana Hukum Islam Dan Kemanusiaan 12 (2): 193. doi:10.18326/ijtihad.v12i2.193215.

Saragih, Hendra Maujana. 2017. "Indonesia Dan Responsibility To Protect Etnis Muslim Rohingnya Myanmar.” FOKUS Jurnal Kajian Keislaman Dan Kemasyarakatan 2 (2): 10624.

Sawal, Indah Angraini. 2017. "Implikasi Krisis Kemanusiaan Rohingya Di Myanmar Terhadap Negara-Negara ASE- 
ISMAIL SUARDI WEKKE, ET AL.

AN.” Universitas Hasanuddin.

Siddiqui, Habib. 2005. "A Long History of Injustice Ignored: Rohingya: The Forgotten People of Our Time." Theamericanmuslim.Org. http://www.islamawareness.net/Asia/Burma/myanmar_article0005.html.

Starke, Joseph Gabriel. 1989. Introduction to International Law. Sidney: Butterworths.

Tampubolon, Jeremia Suluh Kaos, Abdul Rahman, and Chairul Bariah. 2013. "Perlindungan Dan Penegakan HAM Di ASEAN Terhadap Manusia Perahu Rohingya Dalam Status Sebagai Pengungsi Menurut Hukum Internasional.” Journal of International Law 1 (3).

Thontowi, Jawahir. 2013. "Perlakuan Pemerintah Myanmar Terhadap Minoritas Muslim Rohingya Perspektif Sejarah Dan Hukum Internasional." Pandecta: Research Law Journal 8 (1). doi:10.15294/PANDECTA.V8I1.2359.

Yulia Hartati, Anna. 2013. "Studi Eksistensi Etnis Rohingya Di Tengah Tekanan Pemerintah Myanmar.” Jurnal Hubungan Internasional 2 (1): 7-17. doi:10.18196/hi.2013.0022.717.

Zarni, Maung, and Alice Cowley. 2014. "The Slow-Burning Genocide of Myanmar's Rohingya." Pacific Rim Law \& Policy Journal 23 (3). University of Washington School of Law.

Zawacki, Benjamin. 2013. “Defining Myanmar's Rohingya Problem.” Human Rights Brief 20 (3): 18-25. 